\title{
Quality of Handroanthus serratifolius (Vahl) S. O. Grose seeds evaluated by the electrical conductivity test ${ }^{1}$
}

\author{
Qualidade de sementes de Handroanthus serratifolius (Vahl) S. O. Grose avaliada \\ pelo teste de condutividade elétrica
}

Patrícia Cândido da Cruz Silva ${ }^{2 *}$, Rinaldo Cesar de Paula², Tamara Mariel Valdovinos² and Márcio José de Araújo²

\begin{abstract}
The electrical conductivity test (EC) used to evaluate seed vigor is directly related to the integrity of cell membranes, but its use in forest species is still restricted. Thus, the objective of this study is to analyze the efficiency of the EC test to evaluate physiological parameters regarding seed quality and the genetic variability among Handroanthus serratifolius mother trees. Seeds from 15 mother trees were evaluated for germination $(\mathrm{G} \%)$ and germination speed index (GSI). In the EC test, the seeds were imbibed in two water volumes $(75$ and $100 \mathrm{~mL})$ at 20 and $25^{\circ} \mathrm{C}$, and the electrical conductivity was measured after five imbibition periods $(24,48,72,96$, and $120 \mathrm{~h})$. The germination test data were submitted to a randomized block design (RBD) analysis of variance and means were compared by the Scott-Knott test. The EC test was conducted as an RBD in a split-split plot scheme, with interaction unfolding by polynomial regression analysis. The mother trees were divided into four groups regarding G\% and SGI. The EC test separated the mother trees into a larger number of groups, regardless of temperature, volume, and imbibition period. In conclusion, the EC test consisting of imbibition 25 seeds in $75 \mathrm{~mL}$ of deionized water at $20^{\circ} \mathrm{C}$ for $48 \mathrm{~h}$ is suitable for evaluating the physiological quality of seeds and the variability among mother trees of Handroanthus serratifolius (Vahl) S. O. Grose.
\end{abstract}

Key words: Vigor. Leaching. Vigor test.

\begin{abstract}
RESUMO - O teste de condutividade elétrica (CE) na avaliação do vigor das sementes relaciona-se diretamente com a integridade das membranas celulares e seu uso em espécies florestais é, ainda, restrito. Assim, objetivou-se analisar a eficiência desse teste na avaliação da qualidade fisiológica de sementes e da variabilidade entre árvores matrizes de Handroanthus serratifolius. Sementes de 15 matrizes foram avaliadas quanto à germinação (G\%) e ao índice de velocidade de germinação (IVG). No teste de CE foram estudados dois volumes de água (75 e $100 \mathrm{~mL}$ ) e cinco períodos de embebição $(24,48,72,96$ e $120 \mathrm{~h})$ das sementes, a 20 e $25^{\circ} \mathrm{C}$. Os dados do teste de germinação foram submetidos à análise de variância em delineamento de blocos casualizados (DBC), seguido de comparação de médias pelo teste de Scott-Knott, e os do teste de CE foram analisados em DBC em esquema de parcelas sub-subdivididas, com desdobramento da interação por análise de regressão polinomial. As matrizes foram divididas em quatro grupos quanto a G\% e IVG. O teste de condutividade elétrica separou as matrizes em maior número de grupos, independentemente da temperatura, volume e período de embebição. O teste de CE conduzido a $20^{\circ} \mathrm{C}$, com 25 sementes embebidas em $75 \mathrm{~mL}$ de água desionizada por 48 h é adequado para a avaliação da qualidade fisiológica de sementes e da variabilidade entre matrizes de Handroanthus serratifolius (Vahl) S. O. Grose.
\end{abstract}

Palavras-chave: Vigor. Lixiviação. Teste de vigor.

\section{DOI: $10.5935 / 1806-6690.20210044$}

Editor-in-Chief: Eng. Agrônomo, Manoel Barbosa Filho - manoel.filho@ufc.br

*Author for correspondence

Received for publication on 11/05/2020; approved on 12/08/2020

${ }^{1}$ This research was financed by CAPES and the manuscript is part of the thesis submitted by the first author to the School of Agricultural and Veterinary Sciences, Sao Paulo State University (Unesp)

2Department of Agricultural Production Sciences, School of Agricultural and Veterinary Sciences, Sao Paulo State University (Unesp), Jaboticabal-SP, Brazil, patriciacandidocs@gmail.com (ORCID ID 0000-0002-3555-5706), rinaldo.paula@unesp.br (ORCID ID 0000-0001-9088-3924), ta.mariel@hotmail.com (ORCID ID 0000-0001-9132-4753),márcio_ok66@hotmail.com (ORCID ID 0000-0001-7218-3879) 


\section{INTRODUCTION}

The electrical conductivity test (EC) is directly related to the integrity of cell membranes and consists of determining the electrical conductivity of a imbibition solution containing seed samples at a given temperature for a certain period (VIEIRA; KRZYZANOWSKI, 1999). The advantages of this test over other vigor tests are the relatively easy methodology, fast results, and high reproducibility (LEMES et al., 2015). Among the main parameters influencing the test results are the water volume, temperature, and imbibition period. Thus, studies to standardize this test are fundamentally important and should be conducted to allow its use for different seeds of forest species with several application purposes.

In the literature, studies on the electrical conductivity test have been conducted for evaluating the physiological quality of seeds of forest species such as Dictyoloma vendellianum A. Juss (FLÁVIO; PAULA, 2010), Piptadenia moniliformis Benth (PEREIRA et al., 2015), Schinus molle L. (DELAZERI; GARLET; SOUZA, 2016), and Mimosa caesalpiniifolia Benth. (AVELINO et al., 2018). Additionally, the EC test has been used to evaluate the quality of forest seeds from different mother trees, however, the test is not always efficient to discriminate the mother trees regarding their physiological potential (SILVA et al., 2014).

The electrical conductivity test can be used, not only to assess the seed quality but also to determine the variability among parent trees. In these cases, the methods for conducting not only this test but also other vigor tests, require standardized procedures notably for native tree species such as the yellow ipê (Handroanthus serratifolius (Vahl) S. O. Grose) in Brazil, for which this information is relatively scarce.

Handroanthus serratifolius (Vahl) S. O. Grose is a tree species of the family Bignoniaceae, popularly known ipê, ipê-amarelo, ipê-do-cerrado, pau-d'arco, ipê-tabaco, ipê-pardo, pau-d'arco-amarelo, among others (CARRERO et al., 2014). In Brazil, this tree is found in the Amazonia in the North region, in Ceará in the Northeast region, extending to the state of São Paulo in the Southeast region (ZAPPI et al., 2015). It occurs in Seasonal Evergreen Forest, Ombrophilous Forest, and Dense Ombrophilous Forest (LOHMANN, 2018).

The wood of $H$. serratifolius (Vahl) S. O. Grose is widely used in several applications, being highly valued in the market. The species, considered a symbolic tree of Brazil, can reach $25 \mathrm{~m}$ in height, is used in urban afforestation, and recommended for reforestation and forest restoration of degraded areas, especially in saline soils (LOHMANN, 2018).
To this end, the objective of this study was to analyze the efficiency of the electrical conductivity test for evaluating the physiological parameters regarding seed quality and the variability among mother trees of Handroanthus serratifolius (Vahl) S. O. Grose.

\section{MATERIAL AND METHODS}

Open pollination seeds of Handroanthus serratifolius (Vahl) S. O. Grose were obtained from fruits harvested from 15 parent trees in September 2017 , corresponding to the time of fruiting of the species in the region. The fruits at the beginning of dehiscence were duly identified by mother trees, georeferenced (Table 1), and registered in the National System of Genetic Resources (SisGen) under the number A2AA3D2.

After harvesting, the fruits were dried in the shade naturally, in an airy environment with varying temperature and relative humidity, until the opening was completed, after 14 days. Subsequently, to ensure seed quality and homogeneity, seeds were processed on a laboratory bench and the process consisted of removing hatched and broken seeds, as well as those damaged by insects, and rotten seeds. The seeds were then packed in Kraft paper bags, properly identified, and stored in an air-conditioned room $\left(20-22{ }^{\circ} \mathrm{C}\right.$ and $40-50 \%$ relative humidity), for 30 days until the implementation of the experiment. At that time, the tests were carried out and the following parameters were determined.

Seed water content - two replications of 20 seeds per mother tree were placed in an oven at $105 \pm 3{ }^{\circ} \mathrm{C}$ for 24 hours (BRASIL, 2009). Initially, the seeds were kept on a laboratory bench for three days, to reduce the water content variation among the samples.

Germination test - five samples of 25 seeds per mother tree were placed in a B.O.D. (Biochemical Oxygen Demand) chamber at $25{ }^{\circ} \mathrm{C}$ and 8 -hour photoperiod. A previously sterilized filter paper roll was used as a substrate, moistened with deionized water in a quantity equivalent to 2.5 times the mass of the non-hydrated paper. The rolls were packed in transparent plastic bags, to avoid evaporative water loss. The seeds were left to germinate while the number of germinated seeds was evaluated daily until the $21^{\text {st }}$ day after the experiment began when the germination stabilized as determined by the criterion of at least a $0.5 \mathrm{~cm}$ radicle emission. At the end of the test, the germination percentage was determined ( $\mathrm{G} \%$ : corresponds to the ratio between germinated seeds and the total number of seeds in each replication), and the germination speed index (GSI), using the equation proposed by Maguire (1962). 
Table 1 - Local geographic coordinates of the parent trees of Handroanthus serratifolius (Vahl) S. O. Grose sampled in the municipality of Jaboticabal, SP

\begin{tabular}{|c|c|c|c|}
\hline Mother Tree & Latitude (S) & Longitude (W) & Altitude (m) \\
\hline 1 & $21^{\circ} 14^{\prime} 780^{\prime \prime}$ & $048^{\circ} 17^{\prime} 781^{\prime \prime}$ & $594 \mathrm{~m}$ \\
\hline 2 & $21^{\circ} 14^{\prime} 740^{\prime \prime}$ & $048^{\circ} 17^{\prime} 800^{\prime \prime}$ & $592 \mathrm{~m}$ \\
\hline 3 & $21^{\circ} 14^{\prime} 742^{\prime \prime}$ & $048^{\circ} 17^{\prime} 801^{\prime \prime}$ & $598 \mathrm{~m}$ \\
\hline 4 & $21^{\circ} 14^{\prime} 747^{\prime \prime}$ & $048^{\circ} 17^{\prime} 803^{\prime \prime}$ & $598 \mathrm{~m}$ \\
\hline 5 & $21^{\circ} 14^{\prime} 660^{\prime \prime}$ & $048^{\circ} 17^{\prime} 729^{\prime \prime}$ & $611 \mathrm{~m}$ \\
\hline 6 & $21^{\circ} 14^{\prime} 480^{\prime \prime}$ & $048^{\circ} 17^{\prime} 290^{\prime \prime}$ & $575 \mathrm{~m}$ \\
\hline 7 & $21^{\circ} 14^{\prime} 394^{\prime \prime}$ & $048^{\circ} 17^{\prime} 472^{\prime \prime}$ & $573 \mathrm{~m}$ \\
\hline 8 & $21^{\circ} 14^{\prime} 534^{\prime \prime}$ & $048^{\circ} 17^{\prime} 562^{\prime \prime}$ & $587 \mathrm{~m}$ \\
\hline 9 & $21^{\circ} 14^{\prime} 563^{\prime \prime}$ & $048^{\circ} 17^{\prime} 603 ”$ & $580 \mathrm{~m}$ \\
\hline 10 & $21^{\circ} 14^{\prime} 579^{\prime \prime}$ & $048^{\circ} 17^{\prime} 645^{\prime \prime}$ & $590 \mathrm{~m}$ \\
\hline 11 & $21^{\circ} 14^{\prime} 518^{\prime \prime}$ & $048^{\circ} 17^{\prime} 674^{\prime \prime}$ & $589 \mathrm{~m}$ \\
\hline 12 & $21^{\circ} 14^{\prime} 519^{\prime \prime}$ & $048^{\circ} 17^{\prime} 673^{\prime \prime}$ & $591 \mathrm{~m}$ \\
\hline 13 & $21^{\circ} 14^{\prime} 606^{\prime \prime}$ & $048^{\circ} 17^{\prime} 854^{\prime \prime}$ & $605 \mathrm{~m}$ \\
\hline 14 & $21^{\circ} 14^{\prime} 448^{\prime \prime}$ & $048^{\circ} 18^{\prime} 339^{\prime \prime}$ & $628 \mathrm{~m}$ \\
\hline 15 & $21^{\circ} 14^{\prime} 449^{\prime \prime}$ & $048^{\circ} 18^{\prime} 322^{\prime \prime}$ & $632 \mathrm{~m}$ \\
\hline
\end{tabular}

Electrical conductivity test - followed the methodology proposed by Vieira and Krzyzanowski (1999), with adaptations as follows. Initially, the seeds were weighed on an analytical balance $(0.001 \mathrm{~g})$, placed in a transparent plastic container $(180 \mathrm{~mL})$, and left to soak in 75 or $100 \mathrm{~mL}$ of deionized water, at 20 and $25^{\circ} \mathrm{C}$, for 24, 48, 72, 96 and $120 \mathrm{~h}$. Five replicates of 25 seeds per mother tree were used. The containers with the water and seeds were covered with transparent plastic bags, to prevent the imbibition water from evaporating.

After each imbibition period $(24,48,72,96$ or $120 \mathrm{~h}$ ), the electrical conductivity was measured using a bench conductivity meter, with a constant of 1.0. The reading results were divided by the respective mass values of the seed samples and the results were expressed as $\mu \mathrm{S} \mathrm{cm}^{-1} \mathrm{~g}^{-1}$.

The germination test followed a randomized block design (RBD) and the electrical conductivity in $\mathrm{RBD}$, in a split-split plot scheme. The plots were the two temperatures $\left(20\right.$ and $\left.25^{\circ} \mathrm{C}\right)$, the subplots the two water volumes (75 and $100 \mathrm{~mL}$ ), and the sub-subplots, the five imbibition periods $(24,48,72,96$, and $120 \mathrm{~h})$.

The data obtained were submitted to the diagnostic residue analysis (CHATTERJEE; HADI, 1986), using the normality tests (ROYSTON, 1995), under the null hypothesis of normality and homoscedasticity (LEVENE, 1961) for assuming data normality, as well as determining outliers and/or influential values using the software R (R CORE TEAM, 2019). The data were subjected to analysis of variance, and since the imbibition period $\mathrm{x}$ temperature $\mathrm{x}$ mother tree $\mathrm{x}$ imbibition water volume (IP x T x M x IV) interaction was significant $(\mathrm{P} \leq 0.05)$ in the electrical conductivity test, the degrees of freedom were decomposed using a polynomial regression analysis up to a third-degree, to describe the leaching pattern of seeds from each mother tree as a function of the imbibition period, for each imbibition temperature-volume combination.

To evaluate the efficiency of the electrical conductivity test and its relationship with the germination of $H$. serratifolius (Vahl) S. O. Grose seeds, as well as to establish a standard protocol for this test, the polynomial regression adjustment up to the third degree was performed for the average germination data of all mother trees as a function of the electrical conductivity values of each imbibition period for each temperature-volume imbibition combination. The chosen equation corresponded to the highest degree with statistical significance $(P \leq 0.05 \%)$. Additionally, and based on the best-adjusted equation, electrical conductivity intervals corresponding to certain germination ranges were established, according to three classes of seed quality: Class I - high-quality seeds, with germination higher or equal to $80 \%$; Class II - medium-quality seeds, with germination between 50 and $79 \%$ and, Class III - low-quality seeds with germination below $50 \%$. 


\section{RESULTS AND DISCUSSION}

Before the germinationand electrical conductivity test, seed water content varied from $7.0 \%$ to $10.9 \%$ among the mother trees (Table 2), probably due to the presence of fruits in different maturation stages. In fact, forest species, as well as fruit from parent plants, show irregular seed maturation (GRUNENNVALDT; CANTARELLI; SALAMONI, 2014).

The mother trees produced seeds with different physiological performances regarding germination percentage and speed, confirming the existing phenotypic variability and quality difference among them. The mother trees were divided into four groups of germination percentage $(\mathrm{G} \%)$ and germination speed index (GSI), with good correspondence in the group composition for both traits. Mother tree 13, with $40 \% \mathrm{G}$ and GSI of 1.106 , presented the poorest quality as shown by the physiological parameters (Table 2). The highest germination values (87 to $98 \%$ ) were found in mother trees 2, 4, 5, 6, 7, 8, 9, and 12 (Table 2).

The highest GSI values (2.444 to 2.800) were observed for mother trees 3, 4, 7, 8, 9 and 12. Among the mother trees in this GSI group, number 3 is not in the highest germination group; on the other hand, mother trees 2, 5 and 6, present in the highest germination group, are not in the highest GSI group. According to the ScottKnott test, groups $a$ and $b$ are high-quality mother trees since seed germination is higher than $80 \%$; group $c$ is intermediate quality with germination between 50 and $79 \%$, and group $d$ is low quality with germination below $50 \%$ (Table 2). Further, it appears that only mother tree 1 is not in the same quality class when considering together germination and germination speed index (GSI).

The IP x T x M x IV interaction was significant in the electrical conductivity test. In general, higher electrical conductivity values occurred at the highest temperature $\left(25^{\circ} \mathrm{C}\right)$, except for mother trees 6 and 12 , in the lowest imbibition volume $(75 \mathrm{~mL})$ while leaching differences increased with the increasing imbibition period (Figure 1).

Furthermore, the temperature is one of the factors affecting the leaching pattern of exudates, so that the quantity and speed of leachate loss are greater at higher temperatures (ZUCARELI et al., 2011). However, these authors reported that the observed changes do not grant a changing classification of seed lots. Likewise, for different tree species, greater differences in electrical conductivity were found as the seed imbibition period increased (ABDO; PAULA, 2017; DALANHOL et al., 2014; FLÁVIO; PAULA, 2010).

The seeds of mother trees 13,14 and 15 released more electrolytes (Figure 1), regardless of the imbibition period. Hence, they present less integrity of the cell membrane system or less capacity to restore this membrane

Table 2 - Water content (\%), germination (G\%) and germination speed index (GSI) of seeds from Handroanthus serratifolius (Vahl) S. O. Grose tree

\begin{tabular}{lccc}
\hline Mothers & Water content $(\%)$ & Germination $(\%)$ & GSI \\
\hline 1 & 7.2 & $84 \mathrm{~b}$ & $1.648 \mathrm{c}$ \\
2 & 7.0 & $94 \mathrm{a}$ & $2.324 \mathrm{~b}$ \\
3 & 8.3 & $82 \mathrm{~b}$ & $2.605 \mathrm{a}$ \\
4 & 9.1 & $87 \mathrm{a}$ & $2.444 \mathrm{a}$ \\
5 & 8.2 & $93 \mathrm{a}$ & $2.064 \mathrm{~b}$ \\
6 & 8.8 & $88 \mathrm{a}$ & $2.218 \mathrm{~b}$ \\
7 & 8.6 & $96 \mathrm{a}$ & $2.560 \mathrm{a}$ \\
8 & 8.4 & $98 \mathrm{a}$ & $2.634 \mathrm{a}$ \\
9 & 8.3 & $95 \mathrm{a}$ & $2.800 \mathrm{a}$ \\
10 & 10.1 & $71 \mathrm{c}$ & $1.832 \mathrm{c}$ \\
11 & 8.6 & $83 \mathrm{~b}$ & $2.336 \mathrm{~b}$ \\
12 & 9.7 & $94 \mathrm{a}$ & $2.679 \mathrm{a}$ \\
13 & 10.9 & $40 \mathrm{~d}$ & $1.106 \mathrm{~d}$ \\
14 & 9.7 & $72 \mathrm{c}$ & $1.853 \mathrm{c}$ \\
15 & 10.2 & $81 \mathrm{~b}$ & $2.140 \mathrm{~b}$ \\
\hline CV (\%) & - & 8.09 & 8.68 \\
\hline
\end{tabular}

Means followed by the same letter do not differ $(\mathrm{P} \leq 0.05)$ by the Scott-Knott test 
system. On the other hand, the imbibition water of seeds from mother trees 1, 2, 3, 4, 5, 6, 7, 8, and 9 exhibited lower electrical conductivity values and were considered more vigorous while the seeds of mother trees 10, 11 and 12 had intermediate electrical conductivity values.

At $25^{\circ} \mathrm{C}$, the electrolyte exudation of mother trees followed a linear pattern in both imbibition volumes, except for mother trees 10 in $100 \mathrm{~mL}$, and 15 in $75 \mathrm{~mL}$, which followed a quadratic pattern, and mother tree 11 in $75 \mathrm{~mL}$, which exhibited a cubic leaching pattern over the evaluation periods (Figure 1).

At $20^{\circ} \mathrm{C}$, the seed electrolyte leaching followed a linear pattern in the two imbibition volumes, except for mother tree 13 in $75 \mathrm{~mL}$, which followed a cubic pattern, and mother tree 14 in $100 \mathrm{~mL}$ with a quadratic pattern. The mother trees $1,2,4,5,7,8,9$, and 12 in $100 \mathrm{~mL}$ did

Figure 1 - Electrical conductivity $\left(\mu \mathrm{S} \mathrm{cm} \mathrm{cm}^{-1} \mathrm{~g}^{-1}\right)$ of seeds from different Handroanthus serratifolius (Vahl) S. O. Grose trees soaked in different conditions and periods: $\mathrm{A}-20^{\circ} \mathrm{C} / 75 \mathrm{~mL}$; B $-20^{\circ} \mathrm{C} / 100 \mathrm{~mL} ; \mathrm{C}-25^{\circ} \mathrm{C} / 75 \mathrm{~mL} ; \mathrm{D}-25^{\circ} \mathrm{C} / 100 \mathrm{~mL}$. (** - significant by t-test at $1 \% ; *$ - significant by t-test at $5 \%$ )
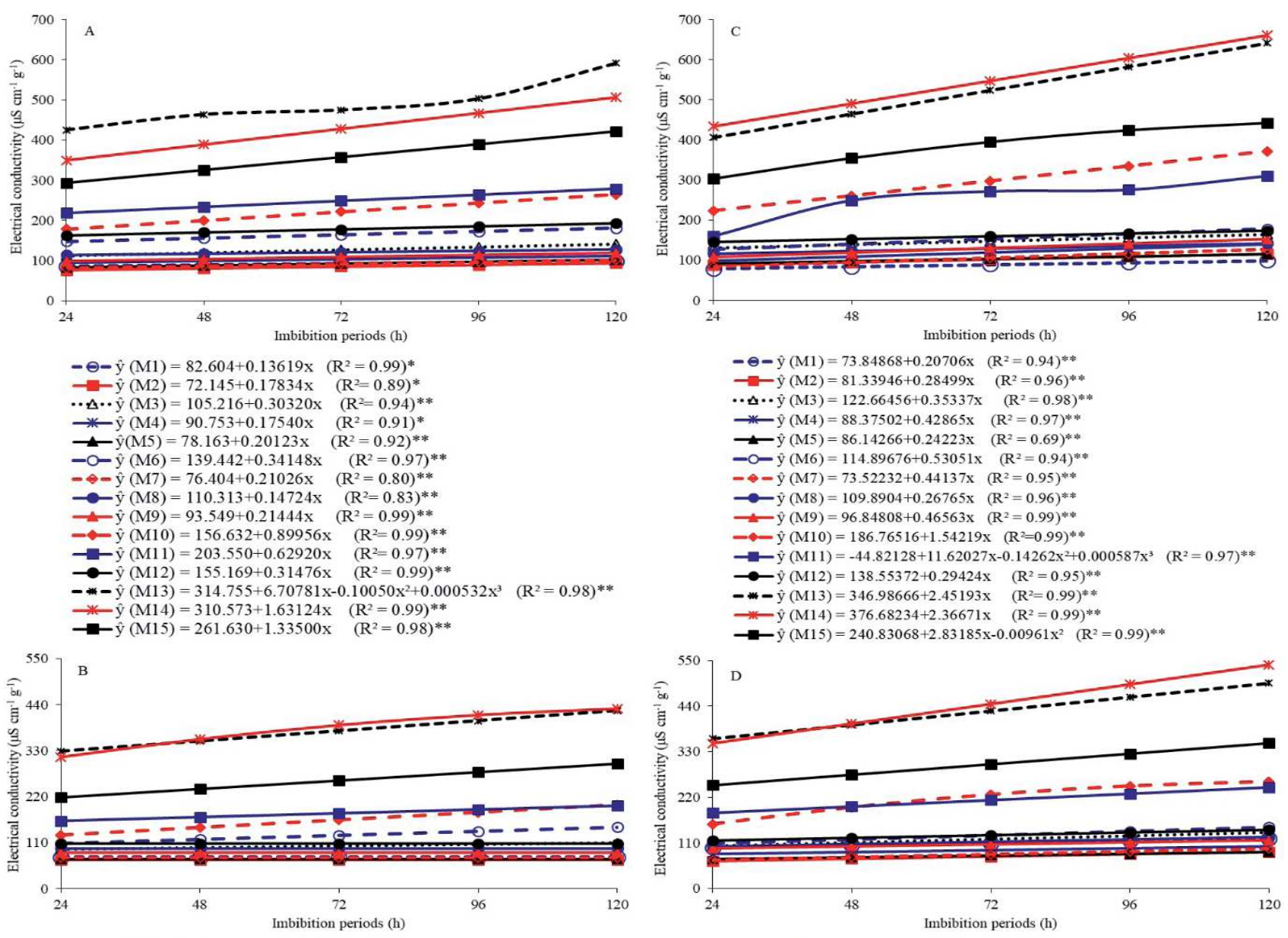

$-\Theta-\bar{y}(\mathrm{M} 1)=75.63912$

$-\bar{y}(\mathrm{M} 2)=69.20448$

$\cdots \Delta \cdots \hat{y}(M 3)=91.25662+0.15287 x\left(R^{2}=0.97\right)^{*}$

$\because-\bar{y}(M 4)=86.51776$

工文 $(\mathrm{M} 5)=70.4846$

- $-\hat{y}(M 6)=97.88048+0.41134 x \quad\left(R^{2}=0.97\right)^{* * *}$

$-\oplus-\bar{y}(M 7)=73.68296$

$\longrightarrow \bar{y}(\mathrm{M} 8)=95.96008$

$\longrightarrow-\bar{y}(\mathrm{M} 9)=86.09596$

$-\otimes-\hat{y}(M 10)=110.2174+0.75155 \mathrm{x} \quad\left(\mathrm{R}^{2}=0.99\right)^{* *}$

$\rightarrow-\hat{\mathrm{y}}(\mathrm{M} 11)=153.28468+0.3776 \mathrm{x} \quad\left(\mathrm{R}^{2}=0.97\right)^{\text {**** }}$

$\longrightarrow \bar{y}(M 12)=108.21516$

$-m-\hat{y}(M 13)=304.60922+1.01162 x \quad\left(R^{2}=0.97\right)^{* * * *}$

$\longrightarrow$ - $\hat{\mathrm{y}}(\mathrm{M} 14)=262.6690+2.36643 \mathrm{x}-0.00806 \mathrm{x}^{2} \quad\left(\mathrm{R}^{2}=0.98\right)^{* *}$

$\longrightarrow-\hat{y}(M 15)=198.27072+0.83916 x \quad\left(R^{2}=0.94\right)^{* * *}$

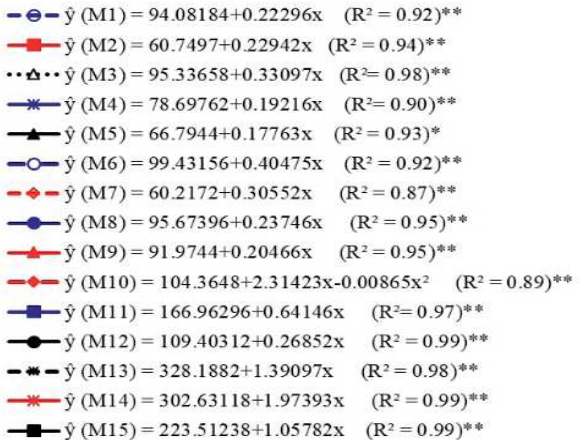


not require a polynomial equation adjustment, probably due to the small variation of electrical conductivity values observed for the studied imbibition periods (Figure 1).

The high leachate release observed in longer imbibition periods can be explained by the disruption and loss of the integrity of cell membranes (VIEIRA; KRZYZANOWSKI, 1999) and probably related to water evaporation, which increases the leachate concentration in the imbibition solution. However, water evaporation is unlikely to have occurred, since the containers where the seeds soaked were wrapped with plastic bags to prevent evaporative water loss. Furthermore, the increase in the electrical conductivity values probably results from the high temperature associated with the long imbibition period, thus changing the conformation of phospholipids present in cell membranes (ATAÍDE et al., 2016).

The lowest electrical conductivity values were obtained, in general, in the largest imbibition volume at the lowest temperature, that is, imbibition in $100 \mathrm{ml}$ at $20{ }^{\circ} \mathrm{C}$, except for mother tree 6 , whose values were remarkably close to those observed at $25^{\circ} \mathrm{C}$, in the same volume (Figure 1). The highest conductivity values in the smallest volume $(75 \mathrm{~mL})$ result from the higher concentration of leachate in the imbibition solution regardless of temperature.

Likewise, similar results were reported for other tree species such as Solanum sessiliflorum Dunal (PEREIRA; MARTINS FILHO, 2012) and Schinus molle L. (DELAZERI; GARLET; SOUZA, 2016). Defining the seed imbibition volume is of paramount importance in the electrical conductivity test, when aiming at standardizing the test (PEREIRA; MARTINS FILHO, 2012) and, as noted, the imbibition volume influences greatly the results, notably when comparing different temperatures for seed incubation.

In some mother trees $(1,2,3,7,8,9,10$ and 14), the electrical conductivity values were similar, probably resulting from the combination of lower temperature/lower imbibition volume $\left(20{ }^{\circ} \mathrm{C} / 75 \mathrm{~mL}\right)$ with higher temperature/higher imbibition volume $\left(25^{\circ} \mathrm{C} / 100 \mathrm{~mL}\right)$, notably in the longer imbibition period. This result indicates that variations in the temperature/volume imbibition combination may provide a similar pattern of electrolyte leaching, so that the reduced leaching speed at lower temperatures may be compensated by the higher concentration of electrolytes, observed in the lower volume of imbibition water.

Considering only the volume and the imbibition period, the results obtained here agree with those reported for Dictyoloma vandellianum A. Juss. (FLÁVIO; PAULA, 2010); higher electrical conductivity values were observed for smaller imbibition volumes and longer times.

To be considered adequate, a vigor test for assessing the physiological parameters regarding seed quality should, preferably, point out the differences not detected by the germination test, or at least, provide the same discrimination of this test that, in general, is used as a reference. Thus, we sought to evaluate whether the electrical conductivity test can be used as a predictor of seed germination of different $H$. serratifolius trees (Figures 2 and 3 ).

The best adjustments of the regression equations for the germination percentage $(\mathrm{G} \%)$ as a function of the electrical conductivity values were obtained at $20{ }^{\circ} \mathrm{C} / 75 \mathrm{~mL}$, as determined by the higher determination coefficient $\left(R^{2}\right)$. The $R^{2}$ ranged from 0.62 to 0.78 , whereas in the other combinations of temperature and imbibition volume, $\mathrm{R}^{2}$ ranged from 0.62 to 0.64 for $20^{\circ} \mathrm{C} / 100 \mathrm{~mL}$, from 0.61 to 0.66 for $25{ }^{\circ} \mathrm{C} / 75 \mathrm{~mL}$, and from 0.61 to 0.64 to $25^{\circ} \mathrm{C} / 100 \mathrm{~mL}$ (Figures 2 and 3).

When the seeds were soaked in $75 \mathrm{~mL}$ at $20{ }^{\circ} \mathrm{C}$, in addition to the higher $\mathrm{R}^{2}$, simple linear and cubic equations adjusted the data whereas, in other situations, only the simple linear equation was adjusted. It is unlikely that the relationship between germination and electrical conductivity is linear, therefore, the $75 \mathrm{~mL}$ soak volume combined with $20{ }^{\circ} \mathrm{C}$, is the most suitable for developing the electrical conductivity test for seeds of $H$. serratifolius (Vahl) S. O. Grose (Figure 2).

In this condition, the 48 and $120 \mathrm{~h}$ imbibition periods provided higher estimates of $\mathrm{R}^{2}(0.78)$, but without major differences in the adjustment regarding the $72 \mathrm{~h}$ imbibition. Thus, the electrical conductivity test for $H$. serratifolius (Vahl) S. O. Grose seeds is recommended to be conducted at $20{ }^{\circ} \mathrm{C}$, with 25 seeds soaked in $75 \mathrm{ml}$ of deionized water for $48 \mathrm{~h}$ (Figure 2B), since it provides a faster assessment with the same precision compared to longer imbibition periods.

Based on this recommendation, Table 3 shows the electrical conductivity values associated with three quality classes of $H$. serratifolius (Vahl) S. O. Grose seeds.

In this way, the mothers of groups $a$ and $b$ (Table 2) are classified as high quality, the mothers of group $c$, as intermediate quality, and the mother 13 of group $d$, of inferior quality. These results can be used in future works to gauge the quality of the species seeds.

In the literature, studies investigating forest species such as Dictyoloma vandellianum A. Juss. (FLÁVIO; PAULA, 2010) and Solanum sessiliflorum Dunal (PEREIRA; MARTINS FILHO, 2012) reported the efficiency of the electrical conductivity test to determine the physiological quality of seeds.

The electrical conductivity test results of the seeds of different mothers are probably likely to have been influenced by genetic variability, for example, of seed chemical composition and, consequently, of the imbibition solution. To this end, Fessel et al. (2010) reported that the vigor of the seeds decreased as the concentration of 
Figure 2 - Germination percentage (G\%) of Handroanthus serratifolius (Vahl) S. O. Grose seeds from different mother trees as a function of electrical conductivity values in 75 and $100 \mathrm{~mL}$ of water at $20{ }^{\circ} \mathrm{C}$ for different imbibition periods (A - $24 \mathrm{~h}, \mathrm{~B}$ - 48 h, C - 72 h, D - 96 h, E - 120 h)
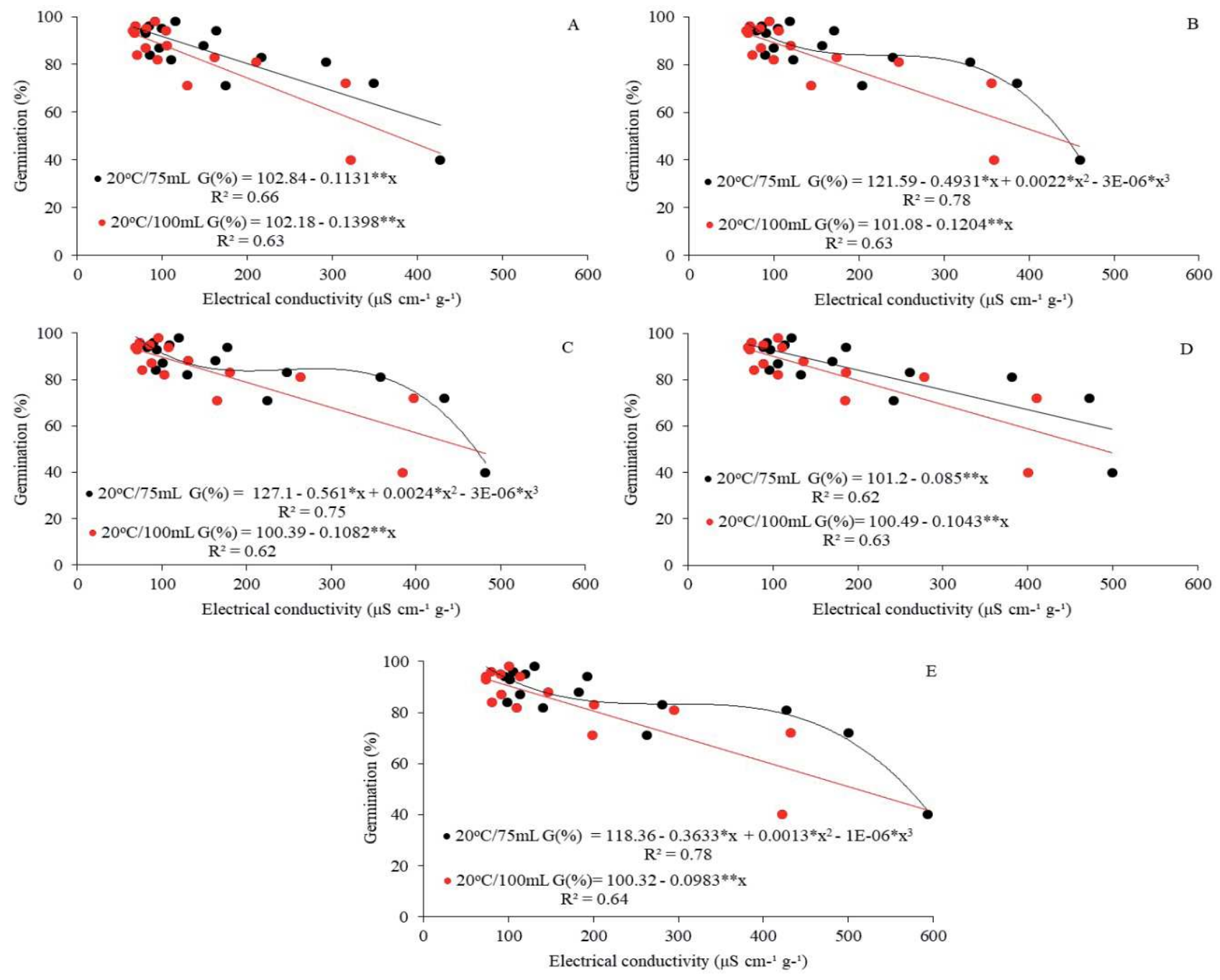

calcium, magnesium and potassium in the imbibition solution increased, with potassium being the main leached ion. The genetic variability among mother trees is also highlighted as one of the possible factors of noncorrespondence between results of the germination process and vigor tests that evaluate the quality of seeds (ROVERI NETO; PAULA, 2017), like the electrical conductivity.

However, in this study, despite the genetic variability among the mother trees, it is considered that the electrical conductivity test efficiently detected consistent differences among the H. serratifolius (Vahl) S. O. Grose matrices depending on the germination pattern. Some mothers did not follow the leaching pattern trend compatible with the results of the germination test, such as mother 15 which, despite good germination, showed high electrolyte leaching and mother 10, with results opposite to that observed for the mother 15 (Table 4). On the other hand, the test efficiently identified the mother with inferior quality seeds (mother 13) in all combinations of temperature-volume-imbibition period studied.

It is noteworthy that the seeds are submitted to optimal conditions in the germination test. However, in the electrical conductivity test, submersion of seeds directly in water can be a stressful factor and, therefore, seeds from different lots (or mother trees) may react differently and some might present damaged cell membranes caused by rapid imbibition while others may not (SILVA; VILLELA, 2011).

Another factor probably influencing, at least in part, the results of the electrical conductivity test is seed mass, which varied among the mother trees (Table 4). Despite not 
Figure 3 - Germination percentage (G\%) of Handroanthus serratifolius (Vahl) S. O. Grose seeds from different mother trees as a function of electrical conductivity values in 75 and $100 \mathrm{~mL}$ of water at $25^{\circ} \mathrm{C}$ for different imbibition periods $(\mathrm{A}-24 \mathrm{~h}, \mathrm{~B}-48 \mathrm{~h}, \mathrm{C}$ - 72 h, D - 96 h, E - 120 h)
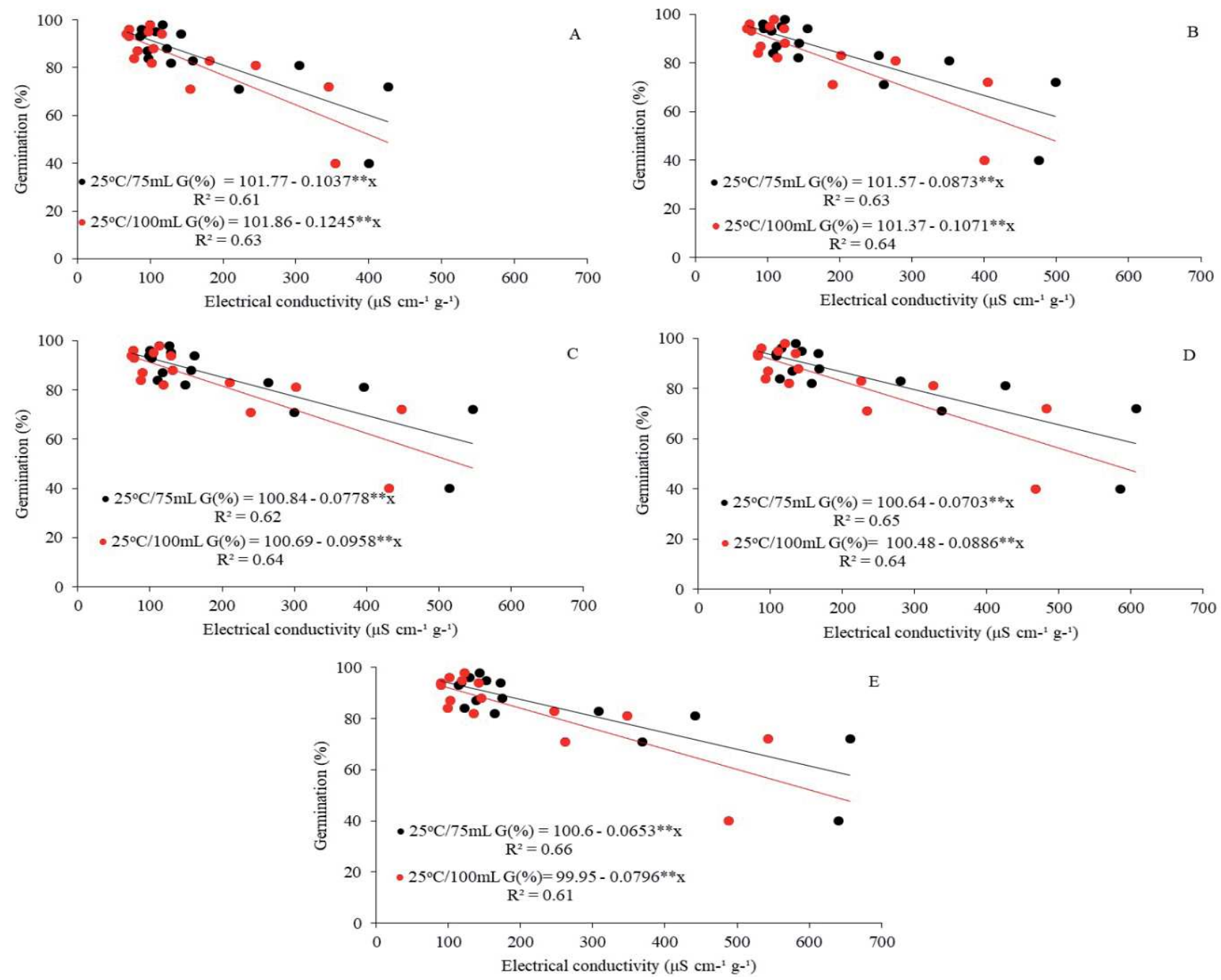

Table 3 - Ranges of electrical conductivity (EC) obtained by imbibition the seeds in $75 \mathrm{~mL}$ of water at $20{ }^{\circ} \mathrm{C}$ for $48 \mathrm{~h}$ and their correspondence with the seed germination values (\%) of mother trees of Handroanthus serratifolius (Vahl) S. O. Grose

\begin{tabular}{lcc}
\hline $\mathrm{EC}\left(\mu \mathrm{S} \mathrm{cm}^{-1} \mathrm{~g}^{-1}\right)^{*}$ & Germination $(\%)$ & Seed Classification \\
\hline$<320$ & $>81$ & High quality \\
$320-440$ & $50-80$ & Intermediate quality \\
$>440$ & $<50$ & Low quality \\
\hline
\end{tabular}

* Values obtained from the adjusted regression, as shown in Figure 2B

being entirely eliminated, this factor influence is minimized by expressing the electrical conductivity as the quotient between the electrical conductivity of the seed imbibition solution and the respective seed mass in the imbibition.

The electrical conductivity test is characterized by ease of evaluation, speed and reproducibility of results. The obtained germination regression equations as a function of electrical conductivity, allow us to recommend this test to evaluate the physiological quality of H. serratifolius (Vahl) S. O. Grose seeds. Additionally, this test can be useful to study genetic variability and divergence between the parent plants of the species. 
Table 4 - Average germination (G\%), electrical conductivity (CE, $\left.\mu \mathrm{S} \mathrm{cm}{ }^{-1} \mathrm{~g}^{-1}\right)$, and mass $(\mathrm{g})$ of 25 seeds of each mother tree of Handroanthus serratifolius (Vahl) S. O. Grose

\begin{tabular}{|c|c|c|c|}
\hline Mother & Germination $^{1}$ & $\mathrm{EC}^{1,2}$ & Mass of 25 seeds \\
\hline 1 & $84 \mathrm{~b}$ & $89.61 \mathrm{a}$ & 1.693 \\
\hline 2 & $94 \mathrm{a}$ & $79.57 \mathrm{a}$ & 1.615 \\
\hline 3 & $82 \mathrm{~b}$ & $122.18 \mathrm{c}$ & 1.197 \\
\hline 4 & $87 \mathrm{a}$ & $99.57 \mathrm{a}$ & 1.217 \\
\hline 5 & $93 \mathrm{a}$ & $90.34 \mathrm{a}$ & 1.699 \\
\hline 6 & $88 \mathrm{a}$ & $156.62 \mathrm{~d}$ & 1.223 \\
\hline 7 & $96 \mathrm{a}$ & $85.49 \mathrm{a}$ & 1.457 \\
\hline 8 & $98 \mathrm{a}$ & $117.74 \mathrm{c}$ & 1.958 \\
\hline 9 & $95 \mathrm{a}$ & $104.16 \mathrm{~b}$ & 1.144 \\
\hline 10 & $71 \mathrm{c}$ & $203.48 \mathrm{e}$ & 0.896 \\
\hline 11 & $83 \mathrm{~b}$ & $239.20 \mathrm{f}$ & 0.936 \\
\hline 12 & $94 \mathrm{a}$ & $170.31 \mathrm{~d}$ & 0.934 \\
\hline 13 & $40 \mathrm{~d}$ & $459.65 \mathrm{i}$ & 0.572 \\
\hline 14 & $72 \mathrm{c}$ & $385.38 \mathrm{~h}$ & 0.860 \\
\hline 15 & $81 \mathrm{~b}$ & $330.32 \mathrm{~g}$ & 0.701 \\
\hline
\end{tabular}

${ }^{1}$ - Means followed by the same letter do not differ by Scott-Knott at $5 \% .{ }^{2}$ - electrical conductivity of the seed imbibition solution at $20^{\circ} \mathrm{C}$, in $75 \mathrm{~mL}$ of water after $48 \mathrm{~h}$

\section{CONCLUSIONS}

The electrical conductivity test conducted with 25 seeds soaked in $75 \mathrm{~mL}$ of deionized water at $20^{\circ} \mathrm{C}$ for $48 \mathrm{~h}$, is suitable for assessing the physiological quality of seeds and variability among trees of Handroanthus serratifolius (Vahl) S. O. Grose, showing agreement with the germination test.

\section{ACKNOWLEDGMENTS}

The authors thank the Coordination for the Improvement of Higher Education Personnel - Brazil (CAPES) - Financing Code 001 for the support to carry out this work. To the National Council for Scientific and Technological Development (CNPq) for granting the second author a Research Productivity scholarship (Process 306734/2018-4).

\section{REFERENCES}

ABDO, M. T. N.; PAULA, R. C. Electrical conductivity test for the determination of the physiological seed quality of Croton floribundus Spreng-Euphorbiaceae. International Journal of Current Research, v. 9, n. 7, p. 54414-54419, 2017.
ATAÍDE, G. M. et al. Alterações fisiológicas durante a hidratação de sementes de Dalbergia nigra ((Vell.) Fr. All. ex Benth.). Ciência Florestal, v. 26, n. 2, p. 615-625, 2016.

AVELINO, M. C. S. et al. Testes bioquímicos de integridade de membranas na avaliação do vigor de sementes de Mimosa caesalpiniifolia Benth. Revista de Ciências Agrárias, v. 41, n. 1, p. 100-108, 2018.

BRASIL. Ministério da Agricultura, Pecuária e Abastecimento. Secretaria de Defesa Agropecuária. Regras para análise de sementes. Brasília: MAPA/ACS, 2009. 395 p.

CARrero, G. C. et al. Árvores do Sul do Amazonas: guia de espécies de interesse econômico e ecológico. Manaus: Idesam, 2014. $57 \mathrm{p}$.

CHATTERJEE, S.; HADI, A. S. Influential observations, high leverage points, and outliers in linear regression. Statistical Science, v. 1, n. 3, p. 379-393, 1986.

DALANHOL, S. J. et al. Teste de condutividade elétrica em sementes de Bowdichia virgilioides Kunth. Revista Floresta e Ambiente, v. 21, n. 1, p. 69-77, 2014.

DELAZERI, P.; GARLET, J.; SOUZA, G. F. Electrical conductivity test in batches of Schinus molle L. seeds. Revista Floresta e Ambiente, v. 23, n. 3, p. 413-417, 2016.

FESSEL, S. A. et al. Teste de condutividade elétrica em sementes de soja armazenadas sob diferentes temperaturas. Bragantia, v. 69, n. 1, p. 207-214, 2010. 
FLAVIO, J. J. P.; PAULA, R. C. D. Testes de envelhecimento acelerado e de condutividade elétrica em sementes de Dictyoloma vendellianum A. Juss. Scientia Forestalis, v. 38, n. 87, p. 391-399, 2010.

GRUNENNVALDT, R. L.; CANTARELLI, E. B.; SALAMONI, A. T. Armazenamento e viabilidade de sementes de Cabralea canjerana (Vell.) Mart. Comunicata Scientiae, v. 5, n. 1, p. 98-105, 2014.

LEMES, E. S. et al. Avaliação do potencial fisiológico de lotes de aveia preta por meio do teste de condutividade elétrica. Tecnologia \& Ciência Agropecuária, v. 9, n. 2, p. 5-10, 2015.

LEVENE, H. Robust tests for equality of variances. In: OLKIN, I. et al. (ed.). Contributions to probability and statistics: essays in honor of Harold Hotelling. Palo Alto: Stanford University Press, 1961. p. 279-292.

LOHMANN, L. G. Bignoniaceae in Lista de Espécies da Flora do Brasil, 2018. Disponível em: http://floradobrasil.jbrj.gov.br/ jabot/floradobrasil/FB117466. Acesso em: 1 maio 2018.

MAGUIRE, J. D. Speed of germination aid selection and evaluation for seedling emergence and vigour. Crop Science, v. 2, n. 2, p. 176-177, 1962.

PEREIRA, K. T. O. et al. Electrical conductivity test in Piptadenia moniliformis Benth. seeds. Journal of Seed Science, v. 37, n. 4, p. 199-205, 2015.

PEREIRA, M. D.; MARTINS FILHO, S. Adequação da metodologia do teste de condutividade elétrica para sementes de cubiu (Solanum sessiliflorum DUNAL). Revista Agrarian, v. 5, n. 16, p. 93-98, 2012.
R CORE TEAM. R: a language and environment for statistical computing. Vienna, Austria: R Foundation for Statistical Computing, 2019. Available on: https://www.R-project.org/. Access on: March 20, 2019.

ROVERI NETO, A.; PAULA, R. C. Variabilidade entre árvores matrizes de Ceiba speciosa St. Hil para características de frutos e sementes. Revista Ciência Agronômica, v. 48, n. 2 , p. 318-327, 2017.

ROYSTON, P. REMARK AS R94: a remark on algorithm AS 181: the W-test for normality. Journal of the Royal Statistical Society, v. 44, n. 4, p. 547-551, 1995.

SILVA, K. B. et al. Variabilidade da germinação e caracteres de frutos e sementes entre matrizes de Sideroxylon obtusifolium (Roem. \&Schult.) T.D. Penn. Revista Eletrônica de Biologia, v. 7, n. 3, p. 281-300, 2014.

SILVA, K. R. G.; VILLELA, F. A. Pré-hidratação e avaliação do potencial fisiológico de sementes de soja. Revista Brasileira de Sementes, v. 33, n. 2, p. 331-345, 2011.

VIEIRA, R. D.; KRZYZANOWSKI, F. C. Teste de condutividade elétrica. In: KRZYZANOWSKI, F. C.; VIEIRA, R. D.; FRANÇA NETO, J. B. (ed.). Vigor de sementes: conceitos e testes. Londrina: ABRATES, 1999. p. 4.1-4.26.

ZAPPI, D. C. et al. Growing knowledge: an overview of seed plant diversity in Brazil. Rodriguésia, v. 66, n. 4, p. 10851113, 2015.

ZUCARELI, C. et al. Métodos e temperaturas de hidratação na qualidade fisiológica de sementes de milho. Revista Ciência Agronômica, v. 42, n. 3, p. 684-692, 2011. 